\title{
PENGARUH KONSELING TERHADAP BEBAN KELUARGA DALAM MERAWAT ORANG DENGAN GANGGUAN JIWA
}

\author{
Ilma Widiya Sari ${ }^{1}$
}

${ }^{1}$ Program Studi Keperawatan, STIKES Estu Utomo Boyolali

Email: ilmawidi@gmail.com

\begin{abstract}
ABSTRAK
Gangguan jiwa menjadi permasalahan serius dan terus mengkhawatirkan. Prevalensi kasus gangguan jiwa mengalami peningkatan setiap tahunnya. Keluarga sebagai unit paling dekat dengan orang dengan gangguan jiwa dan menjadi penyedia perawatan utama bagi penderita. Keluarga beperan besar dalam menentukan cara atau perawatan yang diperlukan penderita di rumah. Ketika satu anggota keluarga mengalami gangguan jiwa, maka seluruh anggota keluarga turut merasakan dampak negatif. Adanya tambahan peran keluarga dalam merawat anggota keluarga dengan gangguan jiwa menyebabkan munculnya tekanan atau beban dalam keluarga yang dapat mempengaruhi kondisi fisik, psikologis, sosial dan ekonomi. Konseling untuk keluarga dibutuhkan sebagai media perantara guna membantu keluarga mengatasi berbagai permasalahan dalam kehidupan. Konseling bagi keluarga dapat menjawab berbagai pertanyaan yang menganggu pikiran serta tingkah lakunya. Penelitian bertujuan menguji pengaruh konseling terhadap beban keluarga dalam merawat orang dengan gangguan jiwa. Penelitian ini menggunakan metode quasi eksperimen dengan rancangan post-test and pre-test one group design. Sampel penelitian ini adalah 52 responden dari keluarga yang mempunyai orang dengan gangguan jiwa. Pengambilan sampel dilakukan dengan teknik simple random sampling. Analisis data bivariat untuk menguji pengaruh secara statistik menggunakan paired t-test. Hasil uji bivariat secara statistik menunjukkan perbedaan nilai rata-rata beban keluarga sebelum dan setelah intervensi, nilai p lebih kecil daripada nilai alpha $(0,00<0,05)$. Dengan demikian dapat disimpulkan bahwa ada pengaruh konseling terhadap beban keluarga dalam merawat orang dengan gangguan jiwa.
\end{abstract}

Kata Kunci: beban keluarga; konseling; orang dengan gangguan jiwa

\begin{abstract}
Mental disorders become a serious problem. The prevalence of mental disorders has increased every year. The family as the closest unit to people with mental disorders and be the main care giver for sufferers. Families as a big role in determining the care needed by sufferers at home. When one family member experiences a mental disorder, all family members also feel the negative effects. The additional role of the family in caring for family members with mental disorders causes the emergence of pressure or burden in the family that can affect physical, psychological, social and economic conditions. Family counseling is needed for media to help families overcome various problems in life as a whole. The role of counseling is the family can answer all questions that disturb the mind and behavior so that the family is able to solve the problem. This research aims to determine the effect of counseling on family burdens in caring for people with mental disorders. This study uses a quasi-experimental method with a post-test and pre-test one group design. The sample taken in this study is a family that has 76 people with mental disorders. Sampling technique using simple random sampling. Bivariate analysis using paired t-test. Bivariate test showed yhe differences in the average value of the family burden before and after the intervention, where the $p$ value is smaller than the alpha (0.00<0.05). It can be concluded that there is an effect of counseling on family burdens in caring for people with mental disorders.
\end{abstract}

Keywords: counseling; family burdens; mental disorders 


\section{PENDAHULUAN}

Gangguan jiwa menjadi permasalahan serius dan terus mengkhawatirkan. World Health Organization (WHO) melaporkan satu dari empat orang di dunia pernah menderita gangguan jiwa, sekarang sekitar 450 juta orang mengalami gangguan jiwa (WHO, 2012). Data WHO pada tahun 2017 menunjukkan bahwa sebanyak 35 juta orang pernah terkena depresi, 60 juta orang menderita bipolar serta 21 juta terdiagnosa skizofrenia. Prevalensi penderita gangguan jiwa menyebabkan beban penduduk global menignkat secara progresif (WHO, 2017).

Prevalensi gangguan jiwa berat mencapai 1,7 per 1000 penduduk Indonesia (Aryawangsa dan Aristuti, 2016). Riset Kesehatan Dasar (Riskesdas) tahun 2018 melaporkan angka prevalensi gangguan jiwa (skizofrenia/psikosis) sebesar 7 per mil (per 1000) rumah tangga. Jumlah prevalensi tersebut diperkirakan mencapai 450 ribu orang dengan gangguan jiwa berat. Proporsi tersebut mengalami peningkatan dari $1,7 \%$ menjadi $7 \%$, cukup signifikan jika dibandingkan Riskesdas tahun 2013 (Kemenkes, 2013; Kemenkes, 2018).

Jawa Tengah merupakan provinsi dengan prevelensi gangguan jiwa yang tinggi di Indonesia, yaitu mencapai 8,7 per 1000 rumah tangga (Kemenkes, 2018). Kabupaten Semarang memiliki angka penderita gangguan jiwa cukup tinggi sesuai data yang di peroleh dari Dinas Kesehatan Kabupaten Semarang tahun 2018. Prevalensi pasien gangguan jiwa di seluruh Kabupaten Semarang tercatat kurang lebih 3553 orang (Dinkes Kabupaten Semarang, 2018).

Keluarga adalah bagian yang penting dalam memberikan perawatan bagi orang dengan gangguan jiwa (Cheryl et al., 2016). Keluarga sebagai unit paling dekat dengan orang dengan gangguan jiwa dan menjadi pemberi perawatan utama bagi penderita. Keluarga beperan besar dalam menentukan cara atau perawatan yang diperlukan penderita di rumah. Jika keluarga merupakan suatu sistem, maka gangguan yang dialami salah satu anggota keluarga bisa mempengaruhi semua sistem. Disfungsi sistem keluarga adalah suatu penyebab masalah pada seluruh anggota keluarga (Keliat, 2006).

Keluarga merupakan suatu sistem terbuka sehingga saat terjadi sebuah perubahan maupun gangguan dari salah satu bagian keluarga tersebut dapat mengakibatkan perubahan pada semua sistem (Nainggolan \& Hidajat, 2013). Salah satu fungsi dan peran keluarga yaitu melaksanakan fungsi afektif dalam pemenuhan kebutuhan psikososial dengan memberikan kasih sayang kepada anggota keluarganya (Friedman, 2010). Adanya tambahan peran keluarga dalam merawat anggota keluarga dengan gangguan jiwa menyebabkan munculnya tekanan atau beban dalam keluarga yang bisa mempengaruhi kondisi fisik, psikologis, sosial dan ekonomi (Darwin, Hadisukanto, \& Elvira, 2013).

Fontaine (2009) menyebutkan ketika satu anggota keluarga mengalami psikotik, maka seluruh anggota keluarga turut merasakan dampak negatif. Kemampuan keluarga merawat penderita ditentukan dari kemampuan dalam manajemen stress. Kelelahan fisik maupun emosi selama memberikan perawatan pada anggota keluarga dengan gangguan jiwa sering dialami keluarga karena berkurangnya toleransi stress. Beban keluarga menjadi tingkat pengalaman tidak menyenangkan pada keluarga yang merupakan dampak dari kondisi yang diderita anggota keluarganya (Fontaine, 2009).

Pemberian konseling kepada keluarga menjadi suatu proses bantuan dalam memecahkan masalah atau gangguan. Konseling diharapkan sebagai media bagi keluarga dalam menyesuaikan diri secara efektif dengan perubahan dan lingkungannya (Purnamaningrum, 
2013). Konseling mempunyai pengaruh yang dalam pada perubahan perilaku, dimana dalam proses konseling diberikan informasi serta pengajaran yang mendalam (Nursalam, 2013).

Konseling merupakan suatu media yang sesuai dalam menciptakan kolaborasi anatar petugas kesehatan dengan keluarga. Konseling pada keluarga dibutuhkan sebagai media perantara guna membantu keluarga mengatasi berbagai permasalahan dalam kehidupan secara menyeluruh. Kebutuhan terhadap konseling pada dasarnya muncul dari dalam maupun luar individu yang menimbulkan pertanyaan tentang apa yang semestinya dilakukan kelurga. Peran konseling pada keluarga bisa menjawab berbagai pertanyaan yang menganggu pikiran serta tingkah laku sehingga keluarga mampu memecahkan permasalahannya (Lubis, 2011).

Hasil studi pendahuluan terhadap beberapa keluarga dengan orang gangguan jiwa menunjukkan bahwa semua responden secara subyektif menyatakan memiliki beban untuk merawat orang gangguan jiwa. Pemberian konseling keluarga yang efektif diharapkan keluarga dapat mengerti dan menerima keadaannya untuk merawat orang dengan gangguan jiwa. Selanjutnya keluarga mampu mengembangkan potensi secara nyata dan menyadari keadaannya sehingga beban dalam merawat orang gangguan jiwa dapat dikurangi atau dihilangkan. Berdasarkan latar belakang dan fenomena yang telah diuraikan, maka penelitian ini bertujuan untuk menguji pengaruh konseling keluarga terhadap penurunan beban keluarga dalam merawat orang dengan gangguan jiwa.

\section{METODE PENELITIAN}

Penelitian ini menggunakan desain penelitian quasi eksperimen dengan bentuk post-test and pretest one group design. Penelitian ini tidak mempunyai kelompok pembanding, namun pengukuran awal (pre-test) yang sudah dilakukan dapat memberikan landasan untuk menguji perubahan yang terjadi setelah pemberian konseling keluarga. Proses konseling keluarga dilakukan konselor dengan menggunakan langkah-langkah konseling, yang meliputi tahap identifikasi masalah, diagnosis, prognosis, treatment, evaluasi atau follow up. Pada akhir penelitian dilakukan pengukuran (post-test) sebagai efek konseling sehingga diketahui perbandingan subyek sebelum dan sesudah diberikan konseling keluarga.

Popualsi penelitian ini adalah keluarga yang mempunyai orang dengan gangguan jiwa. Jumlah sampel yang diambil sebanyak 52 keluarga dengan menggunakan teknik simple random sampling. Penelitian ini mengandung variabel bebas berupa konseling dan variabel terikat yaitu beban keluarga dalam merawat orang dengan gangguan jiwa. Beban keluarga diukur menggunakan kuesioner Disability Assessment Schedule WHODAS II. Kuesioner tersebut diadopsi dari penelitian Sari (2009) yang berjumlah 25 pernyataan, terdiri dari pemahaman dan komunikasi, aktivitas fisik, perawatan diri, bergaul dengan orang lain dan kegiatan sosial.

Data penelitian yang terkumpul selanjutnya dilakukan pengolahan. Analisis univariat dilakukan guna mendeskripsikan tingkat beban keluarga dalam meraawat orang dengan gangguan jiwa sebelum maupun setelah intervensi. Analisis bivariat bertujuan untuk perbedaan beban keluarga saat pre-test dan post-test. Uji normalitas dilakukan terlebih dahulu pada variabel beban keluarga guna menentukan uji statistik yang akan digunakan. Uji normalitas menggunakan uji Kolmogorov-Smirnov dengan jumlah sampel lebih dari 50. Hasil uji normalitas menunjukkan bahwa distribusi data normal (nilai $p>0,05$ ) sehingga analisis bivariat dilakukan dengan uji parametrik menggunakan paired t-test. 


\section{HASIL DAN PEMBAHASAN}

\section{Analisa Univariat}

Analisa univariat mendeskripsikan beban keluarga dalam merawat orang dengan gangguna jiwa disajikan dalam tabel berikut:

Tabel 1. Distribusi Frekuensi Beban Keluarga dalam Merawat Orang dengan Gangguan Jiwa

\begin{tabular}{|c|c|c|c|c|}
\hline \multirow{2}{*}{$\begin{array}{c}\text { Variabel Beban } \\
\text { Keluarga }\end{array}$} & \multicolumn{2}{|c|}{ Sebelum Intervensi } & \multicolumn{2}{|c|}{ Setelah intervensi } \\
\hline & f & $\%$ & $\mathbf{F}$ & $\%$ \\
\hline Tinggi & 30 & 57,7 & 14 & 26,9 \\
\hline Sedang & 22 & 42,3 & 38 & 73,1 \\
\hline Total & 52 & 100 & 52 & 100 \\
\hline
\end{tabular}

Hasil penelitian mendeskripsikan bahwa sebagian besar keluarga memiliki beban yang tinggi dalam merawat orang dengan gangguan jiwa sebelum diberikan intervensi. Beban keluarga didefinisikan sebagai pengalaman keluarga saat merawat anggota yang mengalami gangguan jiwa (Glanville \& Dixon, 2005). Secara umum, beban keluarga dalam merawat orang dengan gangguan jiwa diklasifikasikan menjadi dua dimensi, yaitu beban secara objektif dan beban secara subjektif (Mohr, 2006; WHO, 2008). Beban objektif menunjukkan masalah yang sering dialami keluarga dalam kehidupan sehari-hari, seperti keterbatasan waktu, aktivitas kerja, kegiatan sosial, menurunnya pendapatan serta terganggunya rutinitas dalam rumah tangga dan hubungan antar anggota keluarga. Beban subjektif mengacu pada dampak psikologis yang negatif dalam keluarga, mencakup perasaan kehilangan, kecemasan, depresi serta perasaan malu (WHO, 2008).

Hasil penelitian ini juga sejalan dengan penelitian Suryenti (2017) yang memperlihatkan bahwa sebagian besar responden memiliki beban keluarga yang berat. Beban keluarga ialah tingkat pengalaman distress keluarga sebagai akibat dari kondisi anggota keluarga. Kondisi ini mungkin menyebabkan peningkatan stress emosianal dan masalah ekonomi keluarga (Nuraenah et al., 2012). Pada keluarga yang mempunyai orang dengan gangguan jiwa, stressor yang diterima berbeda dengan keluarga yang mempunyai masalah kesehatan lain. Stressor dialami oleh keluarga dengan gangguan jiwa lebih dikenal dengan sebutan beban keluarga (family burden) (Ngadiran, 2010). Dampak dari beban keluarga yang dirasakan akan mempengaruhi kemampuan dalam memberikan perawatan kepada penderita. Jika keluarga merasa terbebani kemungkinan kemampuan keluarga untuk merawat penderita akan menurun.

Tabel 1 juga mendeskripsikan bahwa sebagian besar keluarga memiliki beban tingkat sedang setelah pemberian intervensi. Hasil tersebut menunjukkan beban keluarga mengalami penurunan setelah diberikan konseling. Penurunan skor tersebut memang masih dikategorikan dalam tingkat beban sedang tetapi menunjukkan penurunan yang bermakna. Hasil penelitian ini sesuai dengan penelitian Dopp (2008) dan Wardaningsih (2007) yang memperlihatkan terdapat pengaruh intervensi keluarga dalam menurunkan beban keluarga secara bermakna. Keluarga mendapatkan informasi dan pengetahuan tentang manajemen stress dan beban, peningkatan koping dan adaptasi serta diajarkan latihan dan keterampilan khusus untuk merawat klien dengan gangguan jiwa jika sewaktu-waktu terjadi kekambuhan. 
Pitschel-Walz et al. (2001) meneliti bahwa intervensi pada keluarga menurunkan beban keluarga secara signifikan. Secara spesifik, intervensi keluarga bisa mengurangi pengalaman distress psikologis, memperbaiki fungsi keluarga seerta hubungan antara penderita dengan keluarga. Penurunan beban keluarga dapat dilihat di akhir penelitian, yaitu sesudah pemberian intervensi dimana keluarga menyebutkan bahwa keluarga merasa tidak malu mengakui bahwa salah satu anggota keluarganya mengalami gangguan jiwa hingga keluarga lebih percaya diri saat bergaul dalam masyarakat.

\section{Uji Hipotesis}

Analisa bivariat untuk menguji perbedaan beban keluarga dalam merawat orang dengan gangguan jiwa sebelum dan setelah intervensi dianalisis dengan paired t-test. Hasil analisis tersebut disajikan pada tabel berikut:

Tabel 2. Analisis Perbedaan Beban Keluarga dalam Merawat Orang dengan Gangguan Jiwa Sebelum dan Setelah Intervensi

\begin{tabular}{|c|c|c|c|c|}
\hline $\begin{array}{l}\text { Variabel Beban } \\
\text { Keluarga }\end{array}$ & Mean & $\begin{array}{c}\text { Standar } \\
\text { Deviasi }\end{array}$ & $\mathbf{T}$ & P value \\
\hline Sebelum intervensi & 75,63 & 7,85 & 7,051 & 0,000 \\
\hline Setelah intervensi & 68,40 & 9,35 & & \\
\hline
\end{tabular}

Hasil analisis tabel 2 menunjukkan bahwa nilai rata-rata beban keluarga merawat orang dengan gangguan jiwa sebelum dan setelah intervensi mengalami penurunan. Perbedaan nilai rata-rata beban keluarga sebelum dan setelah intervensi bermakna secara statistik, dimana nilai $p$ lebih kecil daripada nilai alpha $(0,000<0,05)$. Hasil tersebut menunjukkan bahwa beban keluarga turun secara signifikan setelah diberikan intervensi konseling. Dengan demikian dapat disimpulkan bahwa ada pengaruh konseling terhadap beban keluarga dalam merawat orang dengan gangguan jiwa.

Hasil penelitian ini menunjukkan konseling efektif menurunkan beban keluarga, sejalan dengan penelitian Suryani dan Rahmawati (2018) yang membuktikan bahwa konseling pada keluarga efektif dalam meningkatkan kualitas hidup. Kondisi kelemahan dapat menurunkan kualitas hidup seseorang sehingga perlu diberikan konseling pada keluarga. Konseling pada keluarga membantu sesorang untuk memahami dan memecahkan masalah yang dialami.

Setelah dilakukan konseling, keluarga lebih mampu melaksanakan peran sebagai care giver yang dapat memberikan pengaruh kepada penderita. Keluarga akan merespon penyakit yang dialami anggota keluarga dengan positif, menyesuaikan diri terhadap penyakitnya serta akan memberikan perawatan penyakitnya dengan baik. Dalam proses konseling, keluarga belajar memahami masalah yang sedang dihadapi sehingga dapat lebih bijaksana dalam menyikapi penyakit yang diderita dan akhirnya dapat meminimalkan efek negatif secara psikologis yang muncul (Rahmat, 2010).

Konseling dalam kesehatan adalah suatu usaha yang dilaksanakan perawat guna membantu klien secara holistik saat menghadapi perubahan yang terjadi dengan cara memberikan dukungan emosional, psikologis, intelektual dan spiritual. Konseling sebagai tindakan dari salah satu peran perawat yang bertujuan membantu mengatasi permasalahan klien. Pemberian konseling 
ditujukan untuk menumbuhkan koping adaptif dan menerima realita. Permasalahan klien dapat dipecahkan dengan menguatkan mekanisme koping (Potter \& Perry, 2005).

Konseling memiliki hubungan penting dengan pengetahuan yang diberikan konselor. Hal ini didukung oleh teori yang menyatakan bahwa konseling merupakan proses yang melibatkan seseorang professional dalam usaha menolong orang lain untuk mencapai pemahaman diri, membuat keputusan serta memecahkan masalah. Konseling dikembangkan untuk membantu klien dalam memahami dan menjelaskan pandangan terhadap kehidupan serta guna mencapai tujuan diri melalui pilihan yang diinformasikan dan melalui pemecahan masalah secara emosional (Nasrudin \& Mukkaromah, 2010).

Pemberian konseling secara signifikan menurunkan beban keluarga, baik beban keluarga tinggi maupun sedang sebelum pemberian konseling. Konseling untuk keluarga dalam penelitian ini bertujuan membantu anggota keluarga dalam sistem keluarga untuk mengembangkan potensinya semaksimal mungkin dan permasalahan beban keluarga bisa teratasi. Konseling pada keluarga dilakukan atas dasar keinginan untuk membantu semua anggota keluarga, kerelaan dan kecintaan terhadap keluarga. Selanjutnya konseling yang dilakukan bersama lebih berfokus pada masalah yang berhubungan dengan situasi keluarga dan memandang secara keseluruhan bahwasanya permasalahan yang dialami seorang anggota keluarga menjadi lebih efektif diatasi apabila melibatkan semua anggota keluarga (Willis, 2009).

\section{KESIMPULAN DAN SARAN}

Hasil penelitian menyimpulkan bahwa ada pengaruh konseling terhadap beban keluarga dalam merawat orang dengan gangguan jiwa. Konseling dapat menurunkan beban keluarga dimana keluarga dapat beradaptasi terhadap perubahan dan memahami masalah yang dihadapi. Melalui konseling perawat membantu keluarga dalam memecahkan masalah sehingga bisa menurunkan beban keluarga dalam merawat roang dengan gangguan jiwa.

Keluarga yang mempunyai beban tinggi dalam merawat orang dengan gangguan jiwa perlu diintervensi agar tidak mengganggu sistem keluarga tersebut. Oleh sebab itu, sebaiknya asuhan keperawatan jiwa tidak hanya berfokus kepada individu yang mengalami gangguan jiwa, tetapi pada sistem keluarga. Konseling dapat dijadikan salah satu intervensi pada keluarga yang memiliki orang dengan gangguan jiwa guna menurunkan beban keluarga.

Penelitian ini menggunakan desain quasi experiment tanpa kelompok control sehingga diharapkan penelitian ini dapat dikembangkan menggunakan desain penelitian yang lebih. Selain itu, diharapkan intervensi konseling dapat dikembangkan dalam penelitian untuk mengatasi permasalah kesehatan lainnya.

\section{Ucapan Terima Kasih}

Peneliti mengucapkan terima kasih kepada Yayasan EU dan Puskesmas Bergas serta pihak-pihak yang telah mendukung dalam penelitian yang dilakukan Penulis.

\section{REFERENSI}

Aryawangsa, AAN., Ariastuti, LNP. (2016). Prevalensi dan distribusi faktor risiko depresi pada lansia di wilayah kerja Puskesmas Tampaksiring 1 Kabupaten Gianyar Bali 2015. Intisari Sains Medis, 7(1), 12-23. 
Cheryl, MR., Irene, HKC., Mao, YWW., Bo, FL. \& Cecilia, L. (2016). Family caregivers and outcome of people with schizophrenia in rural China: 14-year follow-up study. Social Psychiatry and Psychiatric Epidemiology, 51(4), 513-520.

Darwin, P., Hadisukanto, G. \& Elvira, SD. (2013). Beban perawatan dan ekspresi emosi pada pramurawat pasien skizofrenia. Jurnal Indon Med Assoc, 63 (2), 46-51.

Dinas Kesehatan Kabupaten Semarang. (2018). Profil Kesehatan Kabupaten Semarang. Semarang: DKK.

Dopp, P. (2008). Single \& multi family network intervention: an integrative response to serious mental illness. United States: Proquest, Umi Dissertation Publishing.

Friedman MM, Bowden VR, \& Jones EG. (2010). Buku ajar keperawatan keluarga: riset, teori, dan praktik. Jakarta: EGC.

Fontaine, KL. (2009). Mental health nursing. New Jersey: Pearson Education.Inc

Glanville, DN. \& Dixon, L. (2005). Caregiver burden, family treatment approaches and service use in families of patients with schizophrenia. The Israel Journal of Psychiatry \& Related Sciences, 42(1), 15-22.

Keliat, BA. (2006). Peran serta keluarga dalam perawatan klien gangguan jiwa. Jakarta: EGC.

Kementerian Kesehatan. (2013). Riset kesehatan dasar tahun 2013. Jakarta: Kemenkes RI.

Kementerian Kesehatan. (2018). Riset kesehatan dasar tahun 2018. Jakarta: Kemenkes RI.

Lubis, N. (2011). Memahami dasar-dasar konseling dalam teori dan praktik. Jakarta: Kencana Prenada Media Group

Mohr, WK. (2006). Psychiatric mental health nursing (6 th edition). Philadelpia: Lippincott Williams \& Wilkins.

Nainggolan, N. J. \& Hidajat, L. L. (2013). Profil kepribadian dan psychological well-being caregiver skizofenia. Jurnal Soul, 6 (1), 21-42.

Nasrudin, Mukkaromah, I. (2010). Keefektifan konseling keluarga terhadap pemberantasan demam berdarah dengue. Jurnal Edu Health, 1(1), 56-64.

Ngadiran, A. (2010). Studi fenomena pengalaman keluarga tentang beban dan sumber dukungan keluarga dalam merawat klien dengan halusinasi (Tesis). FIK UI, Depok.

Nuraenah, Mustikasari, Putri, YSE. (2012). Hubungan dukungan keluarga dan beban keluarga dalam merawat anggota dengan riwayat perilaku kekerasan di RS Jiwa Islam Klender Jakarta Timur. Jurnal Keperawatan Jiwa, 2(1), 41-50.

Nursalam. (2013). Asuhan keperawatan pada pasien terinfeksi. Edisi I. Jakarta: Salemba Medika.

Pitschel-Walz GI., Leucht S., Bäuml J., Kissling W., Engel RR. (2001). The effect of family interventions on relapse and rehospitalization in schizophrenia a meta-analysis. Schizophr Bull, 27(1), 73-92.

Potter, PA. \& Perry, AG. (2005). Fundamental of nursing: concept, process, and practice. Philadelphia: Mosby Years Book Inc.

Purnamaningrum. (2013). Pengaruh metode konseling oleh lay health worker terhadap pengetahuan dan kesertaan skrining kanker leher rahim di Desa Donokerto Kecamatan Turi. Jurnal teknologi Kesehatan, 9(1), 52-57.

Rahmat. (2010). Pengaruh konseling terhadap kecemasan dan kualitas hidup pasien diabetes mellitus di Kecamatan Kebakkramat (Tesis).UNS, Surakarta. 
Sari, H. (2009). Pengaruh family psychoeducation therapy terhadap beban dan kemampuan keluarga dalam merawat klien pasung di Kabupaten Bireuen Nanggroe Aceh Darussalam (Tesis). FIK UI, Depok.

Suryani, Rahmawati. (2018). Efektivitas konseling keluarga terhadap peningkatan kualitas hidup pasien hipertensi. The Shine Cahaya Dunia D-III Keperawatan, 3(1), 30-39.

Suryenti, V. (2017). Dukungan dan beban keluarga dengan kemampuan keluarga merawat pasien resiko perilaku kekerasan di klinik jiwa rumah sakit jiwa Provinsi Jambi tahun 2017. Jurnal Psikologi Jambi, 2(2), 39-46.

Wardaningsih, S. (2007). Pengaruh family psychoeducation terhadap beban dan kemampuan keluarga dalam merawat klien dengan halusinasi di Kabupaten Bantul Yogyakarta (Tesis). FIK UI, Depok.

Willis, SS. (2009). Konseling Keluarga (Family Counseling). Bandung: Alfabeta.

WHO. (2008). The Lancet. London: Elsevier Properties SA.

WHO. (2012). Health education: Theoretical concepts, effective strategies and corecompetencies. Cairo: WHO Regional Office for the Eastern Mediterranean Publishers.

WHO. (2017). Monitoring health for the sdgs, sustainable development goals. Geneva: WHO. 